\title{
Reclassification of Desulfotomaculum auripigmentum as Desulfosporosinus auripigmenti corrig., comb. nov.
}

\author{
Erko Stackebrandt, Peter Schumann, Esther Schüler and Hans Hippe \\ DSMZ - Deutsche Sammlung von Mikroorganismen und Zellkulturen, Mascheroder Weg 1b, \\ 38124 Braunschweig, Germany
}

Correspondence

Erko Stackebrandt

Erko@DSMZ.de

\begin{abstract}
The species Desulfotomaculum auripigmentum is reclassified as Desulfosporosinus auripigmenti corrig., comb. nov. on the basis of morphological and physiological traits, phylogenetic position and chemotaxonomic properties. Characteristics supplementary to those provided in the original description reveal that the type strain, DSM $13351^{\top}$ (=ATCC $700205^{\top}$ ), forms oval, subterminal to terminal spores, possesses LL-diaminopimelic acid and contains MK-7 as the predominant menaquinone, while the whole-cell methanolysate contains even-carbon, straight-chain saturated and mono-unsaturated fatty acids and 1,1-dimethylacetals as major components. DNA-DNA reassociation values below $30 \%$ for Desulfosporosinus orientis DSM $765^{\top}$ and Desulfosporosinus meridiei DSM $13257^{\top}$ demonstrate that strain DSM $13351^{\top}$ shows sufficient genomic differences to maintain its species status. Lack of motility, a smaller cell diameter and the ability to use malate and glycerol as electron donors and fumarate and arsenate as electron acceptors are the main properties that differentiate Desulfosporosinus auripigmenti from the other two species of the genus.
\end{abstract}

The species Desulfotomaculum auripigmentum, type strain ATCC $700205^{\mathrm{T}}\left(=\mathrm{DSM} 13351^{\mathrm{T}}\right)$ (Newman et al., 1997), was affiliated with Desulfotomaculum mainly on the basis of $16 \mathrm{~S}$ rDNA analysis. This non-motile, sausage-shaped, arsenate- and sulfate-reducing Gram-positively staining bacterium, for which spore formation had not been reported, was placed as a phylogenetic neighbour of Desulfotomaculum orientis in the $16 \mathrm{~S}$ rDNA dendrogram of relationships $(96 \cdot 2 \%$ similarity). However, in the same year in which Desulfotomaculum auripigmentum was described, Desulfotomaculum orientis was reclassified as the type species of a new genus, namely Desulfosporosinus, as Desulfosporosinus orientis (Stackebrandt et al., 1997). As the publication processes overlapped each other, none of the two research groups was aware of the other group's work. In 2001, a second species of the genus Desulfosporosinus, Desulfosporosinus meridiei (type strain DSM $13257^{\mathrm{T}}$ ), was described (Robertson et al., 2001) which branched phylogenetically adjacent to Desulfotomaculum auripigmentum DSM $13351^{\mathrm{T}}$ (97.6\% 16S rRNA gene sequence similarity), while the sequence similarity to Desulfosporosinus orientis DSM $765^{\mathrm{T}}$ was slightly lower $(96 \cdot 7 \%)$. Despite the grouping

Published online ahead of print on 21 February 2003 as DOI 10.1099/ ijs.0.02526-0.

The GenBank/EMBL/DDBJ accession numbers for the 16S rRNA gene sequences of Desulfosporosinus auripigmenti DSM $13351^{\top}$ and Desulfosporosinus orientis DSM 7493 are AJ493051 and AJ493052, respectively. of a Desulfotomaculum species between two Desulfosporosinus species, the generic affiliation of Desulfotomaculum auripigmentum remained unchallenged.

As the 16S rRNA gene sequence of the type strain of Desulfotomaculum auripigmentum, ATCC $700205^{\mathrm{T}}$, comprised only 1263 nt (GenBank accession no. U85624), the sequence analysis of strain DSM $13351^{\mathrm{T}}$ was repeated (AJ493051), using the method described by Rainey et al. (1996), and the phylogenetic position was reassessed by applying the treeing algorithm of De Soete (1983). Using the new sequence comprising 1532 bases, Desulfotomaculum auripigmentum was found to share $97 \cdot 4$ and $97 \cdot 9 \%$ similarity with Desulfosporosinus orientis DSM $765^{\mathrm{T}}$ and Desulfosporosinus meridiei, respectively. Desulfosporosinus orientis DSM 7439, the 16S rRNA gene sequence of which was also determined in this study (GenBank accession no. AJ493052), was highly related to the type strain DSM $765^{\mathrm{T}}$ (99.5\%), while strain DSM 8344 was significantly less closely related to DSM $765^{\mathrm{T}}(96 \cdot 2 \%)$ (Stackebrandt et al., 1997; Robertson et al., 2001). Strain DSM 8344 showed $97 \cdot 6 \%$ similarity to the type strains of Desulfotomaculum auripigmentum and Desulfosporosinus meridiei. All these strains formed a coherent phylogenetic cluster that formed a sister lineage to the Desulfitobacterium lineage (93.1-94.4\% similarity) (Fig. 1). Members of the genus Desulfotomaculum, described as being phylogenetically heterogeneous and forming three major clusters (Stackebrandt et al., 1997), were less than $90 \%$ similar to members of the 


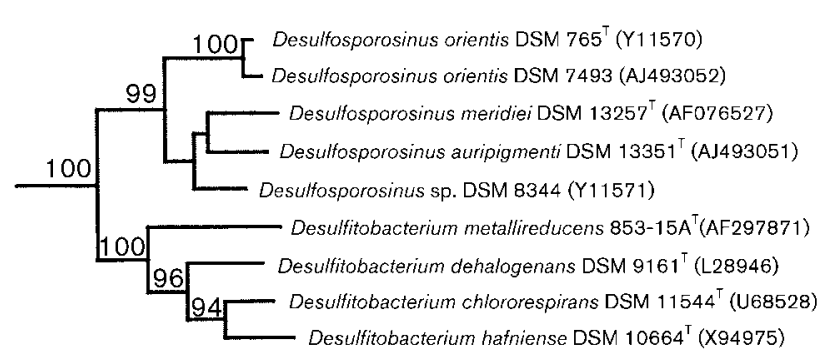

$2 \%$

Fig. 1. Dendrogram of $16 \mathrm{~S}$ rRNA gene sequence relationships (De Soete, 1983), displaying the phylogenetic position of Desulfotomaculum auripigmentum DSM $13351^{\top}$, reclassified as Desulfosporosinus auripigmenti in this study. Numbers at branching points refer to bootstrap values (1000 resamplings). Bar, 2 nucleotide substitutions per 100 sequence positions. The tree was rooted with the 16S rRNA gene sequences of Desulfotomaculum species.

two lineages embracing the genera Desulfosporosinus and Desulfitobacterium.

The phylogenetic clustering of Desulfotomaculum auripigmentum with members of the genus Desulfosporosinus raises the question of whether this species should be reclassified as a species of the genus Desulfosporosinus. The 16S rRNA gene sequences of Desulfosporosinus strains and Desulfotomaculum auripigmentum contain several exclusive signature nucleotides, which clearly distinguish these organisms from members of the genus Desulfitobacterium (Table 1). The respective nucleotides of Desulfotomaculum species are not listed because the species do not constitute a phylogenetically coherent taxon. Members of the genus

Table 1. Oligonucleotide signatures distinguishing members of the genus Desulfosporosinus and Desulfotomaculum auripigmentum from members of the genus Desulfitobacterium

\begin{tabular}{|lcc|}
\hline $\begin{array}{l}\text { 16S rRNA gene } \\
\text { position* }\end{array}$ & $\begin{array}{c}\text { Desulfosporosinus spp., } \\
\text { Desulfotomaculum } \\
\text { auripigmentum }\end{array}$ & $\begin{array}{c}\text { Desulfitobacterium } \\
\text { spp. }\end{array}$ \\
\hline $140-223$ & A-U & U-A \\
$418-425$ & U-A & C-G \\
$443-491$ & U-A & C-G \\
$444-490$ & G-C & A-U \\
$600-638$ & C-G & U-G \\
$1117-1183$ & G-U & A-U \\
$1119-1154$ & A-U & G-C \\
$1310-1327$ & C-G & U-A \\
$1311-1326$ & A-U & U-A \\
$1312-1325$ & G-C & C-G \\
$1313-1324$ & G-C & U-A \\
& & \\
\hline
\end{tabular}

${ }^{\star}$ According to Brosius et al. (1978).
Desulfosporosinus, as well as Desulfotomaculum auripigmentum, possess LL-diaminopimelic acid as the diagnostic amino acid of peptidoglycan, as determined by the methods of Schleifer \& Kandler (1972). However, LLdiaminopimelic acid also occurs in some members of the genus Desulfotomaculum, for example, Desulfotomaculum thermoacetoxidans DSM $5813^{\mathrm{T}}$ and Desulfotomaculum thermobenzoicum subsp. thermobenzoicum DSM 6193 ${ }^{\mathrm{T}}$, and in species of the genus Desulfitobacterium [Desulfitobacterium dehalogenans DSM $9161^{\mathrm{T}}$, Desulfitobacterium hafniense DSM $10664^{\mathrm{T}}$, as well as in Desulfitobacterium sp. strain PCE1 (Gerritse et al., 1992)], whereas Desulfotomaculum aeronauticum DSM $10349^{\mathrm{T}}$, Desulfotomaculum geothermicum DSM $3669^{\mathrm{T}}$ and Desulfotomaculum nigrificans DSM $574^{\mathrm{T}}$ contained meso-diaminopimelic acid (result of this study, except for strain PCE1). Thus, this property is not exclusive taxonomically.

To verify the species status of the two Desulfosporosinus species and of Desulfotomaculum auripigmentum, DNADNA pairing studies were performed between the type strains. DNA was isolated by chromatography on hydroxylapatite by the procedure of Cashion et al. (1977). DNA-DNA hybridization was carried out in $2 \times$ SSC at $65^{\circ} \mathrm{C}$ according to De Ley et al. (1970), using a Gilford System 2600 spectrophotometer (Gilford Instrument Laboratories) equipped with a Gilford 2527-R thermoprogrammer and plotter. While Desulfosporosinus orientis DSM $765^{\mathrm{T}}$ shared $54 \%$ DNA binding with Desulfosporosinus meridiei DSM $13257^{\mathrm{T}}$, the DNA similarity of these type strains to Desulfotomaculum auripigmentum DSM $13351^{\mathrm{T}}$ was 30 and $29 \%$, respectively. DNA-DNA similarity values below $55 \%$ correlated with the moderate $16 \mathrm{~S}$ rRNA gene sequence similarities and confirmed that each of the three species are genomically distinct taxa. This is also reflected by different EcoRI riboprint patterns (Fig. 2) generated by the RiboPrinter (a microbial characterization system; DuPont Qualicon) according to Bruce (1996).

In contrast to the type strains of Desulfosporosinus orientis and Desulfosporosinus meridiei, Desulfotomaculum auripigmentum DSM $13551^{\mathrm{T}}$ is not motile, and spores had not been observed. In this respect, strain DSM $13551^{\mathrm{T}}$ also differs from the genus description of Desulfotomaculum (Campbell \& Singleton, 1986), reported to embrace sporeforming and motile organisms. To determine whether Desulfotomaculum auripigmentum does in fact fail to produce spores, strain DSM $13551^{\mathrm{T}}$ was grown in DSMZ medium no. 641 (Deutsche Sammlung von Mikroorganismen und Zellkulturen Catalogue of Strains, 2001, 7th edn), containing $2.5 \mathrm{~g}$ lactate $1^{-1}$, at $28{ }^{\circ} \mathrm{C}$ for 4 days. Subterminal to terminal ellipsoid spores were formed in some cells (Fig. 3). The same medium was used for obtaining information on chemotaxonomic properties lacking in the original description of Desulfotomaculum auripigmentum, i.e. isoprenoid quinones (Collins et al., 1977; Groth et al., 1996) and cellular fatty acids (Miller, 1982; Sasser, 1990). MK-7 was the principal quinone 


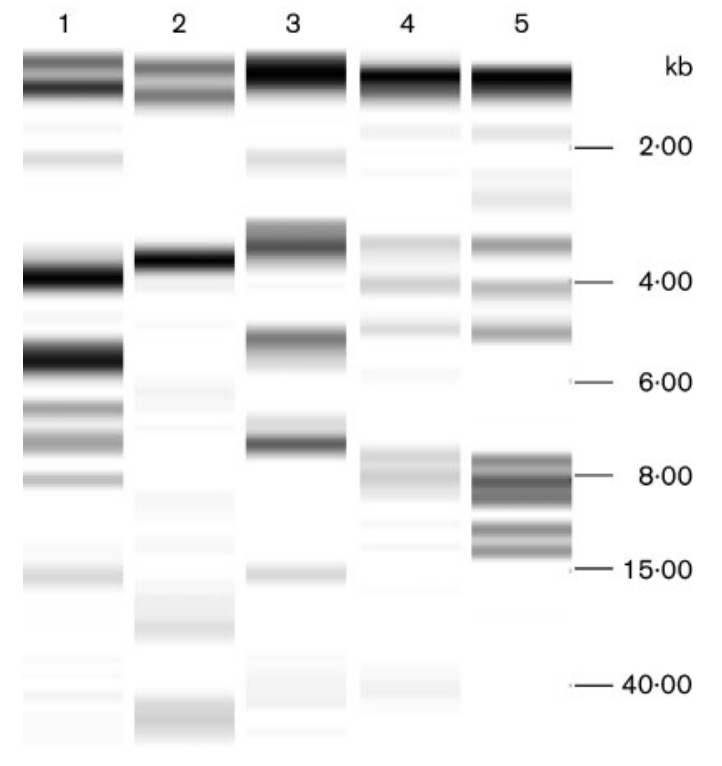

Fig. 2. Riboprint patterns of Desulfosporosinus strains and Desulfosporosinus auripigmenti DSM $13351^{\top}$, generated with EcoRI. Lanes: 1, Desulfosporosinus meridiei DSM $13257^{\top}$; 2, Desulfosporosinus auripigmenti DSM $13351^{\top}$; 3, Desulfosporosinus sp. DSM 8344; 4, Desulfosporosinus orientis DSM $765^{\top} ; 5$, Desulfosporosinus orientis DSM 7439.

(57\%), while MK-5 (40\%) and MK-6 (3\%) were the minor quinones. The major fatty acids ( $>5 \%$ of the total) were even-carbon, straight-chain saturated and monounsaturated fatty acids. 1,1-Dimethylacetals and traces of aldehydes, branched-chain fatty acids and cyclopropane fatty acids occur as well (see species description for the percentage of total values). The fatty acid composition differs from that described for Desulfosporosinus meridiei

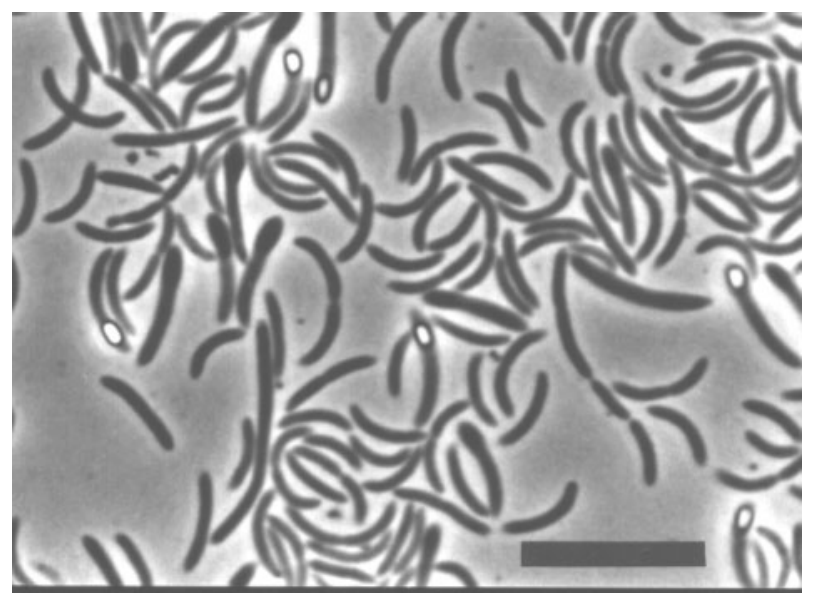

Fig. 3. Phase-contrast micrograph of spore-forming and nonspore-forming cells of Desulfosporosinus auripigmenti. Bar, $10 \mu \mathrm{m}$.
(Robertson et al., 2000) in the lack of substantial amounts of iso- and anteiso-branched-chain fatty acids ( 2.5 versus $29 \%$ ) but confirms the fatty acid composition given in the emended genus description, in which it is stated that members of the genus Desulfosporosinus contain minor amounts of branched-chain fatty acids (Robertson et al., 2001) or even no branched-chain fatty acid (Stackebrandt et al., 1997). We therefore propose, on the basis of the phylogenetic position, common chemotaxonomic properties, sulfate reduction and incomplete oxidation of organic compounds (Table 2), to reclassify Desulfotomaculum auripigmentum as Desulfosporosinus auripigmenti corrig., comb. nov. (auripigmentum, a noun in apposition, has been changed to auripigmenti, the genitive noun). Lack of motility, a smaller cell diameter and the ability to use malate and glycerol as electron donors and fumarate and arsenate as electron acceptors differentiate this species from the other two species of the genus Desulfosporosinus. This transfer demands the emendation of the genus description of Desulfosporosinus.

\section{Emended description of the genus Desulfosporosinus (Stackebrandt et al. 1997, Robertson et al. 2001, emend.)}

Desulfosporosinus [De.sul.fo.spo.ro.si'nus. L. pref. de from; L. n. sulfur sulfur; M.L. n. spora spore; L. n. sinus bend; N.L. masc. n. Desulfosporosinus a spore-forming curved (organism) that reduces sulfur compounds].

Gram-negative rods that have a multi-layered cell wall structure. Endospores present, oval and subterminal to (almost) terminal, causing the cells to swell slightly. Nonmotile or motile with lateral or peritrichous flagella. Strictly anaerobic. If determined, desulfoviridin and cytochrome $c_{3}$ absent and bisulfite reductase $\mathrm{P}_{582}$ present. Sulfate and thiosulfate are reduced to sulfide in the presence of lactate but not in the presence of acetate or fructose. Incomplete oxidation of organic compounds to acetate. Acetate is the fermentation end-product; capable of homoacetogenic growth. Grows autotrophically with hydrogen plus sulfate. LL-Diaminopimelic acid is the diagnostic diamino acid of peptidoglycan. Contains menaquinone with a side-chain with seven isoprene units (MK-7 type). Predominant fatty acids are even-numbered, saturated and unsaturated fatty acids; significant amounts of 1,1-dimethylacetals have been found in Desulfosporosinus auripigmenti; traces of iso- and anteiso-branched-chain fatty acids and cyclopropane fatty acids may occur. The G+C content of the DNA is $41 \cdot 6-$ $45.9 \mathrm{~mol} \%$. Phylogenetically, a member of the ClostridiumBacillus subphylum of Gram-positive bacteria.

The type species is Desulfosporosinus orientis.

\section{Description of Desulfosporosinus auripigmenti corrig., comb. nov.}

Basonym Desulfotomaculum auripigmentum (Newman et al. 1997). Desulfosporosinus auripigmenti [au.ri.pig.men'ti. L. 
Table 2. Some biochemical and chemotaxonomic characteristics of species of the genus Desulfosporosinus, including the reclassified species Desulfosporosinus auripigmenti

ND, Not determined. All of the species share the following properties: LL-diaminopimelic acid is present in the peptidoglycan; oxidation of hydrogen with carbon dioxide; sulfate, thiosulfate and sulfite are used as electron acceptors in the presence of lactate; incomplete oxidation.

\begin{tabular}{|c|c|c|c|}
\hline Property & $\begin{array}{l}\text { Desulfosporosinus } \\
\text { orientis DSM } 765^{T}\end{array}$ & $\begin{array}{c}\text { Desulfosporosinus } \\
\text { meridiei DSM } 13257^{\mathrm{T}}\end{array}$ & $\begin{array}{c}\text { Desulfosporosinus } \\
\text { auripigmenti DSM } 13351^{\mathrm{T}}\end{array}$ \\
\hline Gram staining & Negative & Negative/variable & Negative \\
\hline Morphology & $\begin{array}{l}\text { Curved rods, sometimes } \\
\text { paired }\end{array}$ & $\begin{array}{l}\text { Curved rods, single } \\
\text { or in short chains }\end{array}$ & $\begin{array}{l}\text { Curved rods, sausage-shaped; } \\
\text { sometimes long chains }\end{array}$ \\
\hline Cell diameter $(\mu \mathrm{m})$ & $0 \cdot 7-1 \cdot 0$ & $0 \cdot 7-1 \cdot 1$ & $0 \cdot 4$ \\
\hline Motility & + & + & - \\
\hline Flagella & Peritrichous & Single lateral & - \\
\hline Endospores & Oval, subterminal & Oval, subterminal & $\begin{array}{l}\text { Oval, subterminal to almost } \\
\text { terminal }\end{array}$ \\
\hline \multicolumn{4}{|c|}{ Electron acceptors in the presence of lactate: } \\
\hline Sulfur & $+^{*}$ & + & - \\
\hline Nitrate & - & $+\dagger$ & - \\
\hline Arsenate & - & - & + \\
\hline DMSO, Fe(III) & $+^{*}$ & + & - \\
\hline Fumarate & - & - & + \\
\hline \multicolumn{4}{|l|}{ Electron donors: } \\
\hline Fumarate & $+^{*}$ & - & - \\
\hline Malate & - & - & + \\
\hline Glycerol & $\mathrm{ND}$ & ND & + \\
\hline Oxidation of $\mathrm{H}_{2}$ & + , with $\mathrm{CO}_{2}$ & + , with $\mathrm{CO}_{2}$ & + , with acetate \\
\hline DNA G + C content $(\mathrm{mol} \%)$ & 45 (buoyant density), $45 \cdot 9\left(T_{\mathrm{m}}\right)$ & $47\left(T_{\mathrm{m}}\right)$ & $41 \cdot 6$ (HPLC) \\
\hline
\end{tabular}

${ }^{\star}$ As reported by Robertson et al. (2001).

$†$ Variable, three out of seven strains were reported as positive (Robertson et al., 2001).

neut. n. aurum gold; L. neut. n. pigmentum colour, pigment; N.L. gen. n. auripigmenti of golden pigment, referring to the colour of precipitate (arsenosulfide, $\mathrm{As}_{2} \mathrm{~S}_{3}$ ) which is formed after reduction of arsenate and sulfate].

Phylogenetic and chemotaxonomic data indicate that Desulfotomaculum auripigmentum is more closely related to species of Desulfosporosinus than to any species of Desulfotomaculum. The cultural, morphological and physiological description of the species, given by Newman et al. (1997), is unchanged. In addition to the original description, cells occasionally form oval, subterminal to terminal spores. The diagnostic amino acid of peptidoglycan is LLdiaminopimelic acid; MK-7 is the predominant isoprenoid quinone; MK-5 and MK-6 are minor components. The major fatty acids $(>5 \%)$ are (as percentages of the total) $16: 1$ cis $9(31 \cdot 6 \%), 16: 0(14 \cdot 2 \%), 16: 0$-dimethylacetal $(13 \cdot 4 \%), 18: 1$ cis $9(7 \cdot 5 \%)$ and $18: 1$ cis 9 -dimethylacetal $(7 \cdot 7 \%)$. Smaller amounts (1-5\%) of the following fatty acids are present (percentages of the total are shown in parentheses): $18: 0(2 \cdot 8 \%), 14: 0(2 \cdot 2 \%), 16: 0$-aldehyde (1.9\%), $16: 1$ cis7 $(1.5 \%), 16: 1$ cis 9 -dimethylacetal $(1 \cdot 7 \%)$, $17: 1$ cis8 $(1 \cdot 3 \%), 17: 1$ cis $9(1 \cdot 1 \%), 18: 1$ cis $11(2 \cdot 5 \%)$, $18: 1$ cis $13 \quad(1 \cdot 0 \%), \quad 18: 0$-dimethylacetal $(2 \cdot 0 \%)$ and 18 : 1 cis11-dimethylacetal $(4 \cdot 4 \%)$. Minor amounts of cyclo
$17: 0(0.6 \%)$ are present. The $\mathrm{G}+\mathrm{C}$ content of the DNA is $41 \cdot 6 \mathrm{~mol} \%$.

The type strain is DSM $13351^{\mathrm{T}}\left(=\right.$ ATCC $\left.700205^{\mathrm{T}}\right)$.

\section{Acknowledgements}

The technical assistance of Bettina Sträubler (DNA reassociation), M. Jando (fatty acid analysis) and Anika Vester (chemotaxonomy) is highly appreciated. We thank Stefan Spring for constructive criticism.

\section{References}

Brosius, J., Palmer, M. L., Kennedy, P. J. \& Noller, H. F. (1978). Complete nucleotide sequence of a $16 \mathrm{~S}$ ribosomal RNA gene from Escherichia coli. Proc Natl Acad Sci U S A 75, 4801-4805.

Bruce, J. (1996). Automated system rapidly identifies and characterizes micro-organisms in food. Food Technol 50, 77-81.

Campbell, L. L. \& Singleton, R., Jr (1986). Genus IV. Desulfotomaculum Campbell and Postgate 1965, 361 ${ }^{\mathrm{AL}}$. In Bergey's Manual of Systematic Bacteriology, vol. 2, pp. 1200-1202. Edited by P. H. A. Sneath, N. S. Mair, M. E. Sharpe \& J. G. Holt. Baltimore: Williams \& Wilkins.

Cashion, P., Holder-Franklin, M. A., McCully, J. \& Franklin, M. (1977). A rapid method for the base ratio determination of bacterial DNA. Anal Biochem 81, 461-466. 
Collins, M. D., Pirouz, T., Goodfellow, M. \& Minnikin, D. E. (1977). Distribution of menaquinones in actinomycetes and corynebacteria. J Gen Microbiol 100, 221-230.

De Ley, J., Cattoir, H. \& Reynaerts, A. (1970). The quantitative measurement of DNA hybridization from renaturation rates. Eur J Biochem 12, 133-142.

DeSoete, G. (1983). A least squares algorithm for fitting additive trees to proximity data. Psychometrika 48, 621-626.

Gerritse, J., Renard, V., Pedro Gomes, T. M., Lawson, P. A., Collins, M. D. \& Gottschal, J. C. (1996). Desulfitobacterium sp. strain PCE1, an anaerobic bacterium that can grow by reductive dechlorination of tetrachloroethene or ortho-chlorinated phenols. Arch Microbiol 165, 132-140.

Groth, I., Schumann, P., Weiss, N., Martin, K. \& Rainey, F. A. (1996). Agrococcus jenensis gen. nov., sp. nov., a new genus of actinomycetes with diaminobutyric acid in the cell wall. Int J Syst Bacteriol 46, 234-239.

Miller, L. T. (1982). Single derivatization method for routine analysis of bacterial whole-cell fatty acid methyl esters, including hydroxy acids. J Clin Microbiol 16, 584-586.

Newman, D. K., Kennedy, E. K., Coates, J. D., Ahmann, D., Ellis, D. J., Lovley, D. R. \& Morel, F. M. M. (1997). Dissimilatory arsenate and sulphate reduction in Desulfotomaculum auripigmentum sp. nov. Arch Microbiol 168, 380-388.
Rainey, F. A., Ward-Rainey, N., Kroppenstedt, R. M. \& Stackebrandt, E. (1996). The genus Nocardiopsis represents a phylogenetically coherent taxon and distinct actinomycete lineage: proposal for Nocardiopsaceae fam. nov. Int J Syst Bacteriol 46, 1088-1092.

Robertson, W. J., Franzman, P. D. \& Mee, B. J. (2000). Sporeforming, Desulfosporosinus-like sulphate-reducing bacteria from a shallow aquifer contaminated with gasoline. J Appl Microbiol 88, 248-259.

Robertson, W. J., Bowman, J. P., Franzmann, P. D. \& Mee, B. J. (2001). Desulfosporosinus meridiei sp. nov., a spore-forming sulfatereducing bacterium isolated from gasolene-contaminated groundwater. Int J Syst Evol Microbiol 51, 133-140.

Sasser, M. (1990). Identification of bacteria by gas chromatography of cellular fatty acids. USFCC Newsl 20, 1-6.

Schleifer, K. H. \& Kandler, O. (1972). Peptidoglycan types of bacterial cell walls and their taxonomic implications. Bacteriol Rev 36, 407-477.

Stackebrandt, E., Sproer, C., Rainey, A. F., Burghardt, J., Päuker, O. \& Hippe, H. (1997). Phylogenetic analysis of the genus Desulfotomaculum: evidence for the misclassification of Desulfotomaculum guttoideum and description of Desulfotomaculum orientis as Desulfosporosinus orientis gen. nov., comb. nov. Int J Syst Bacteriol 47, 1134-1139. 